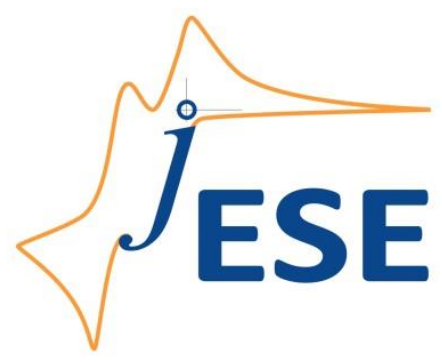

Open Access : : ISSN 1847-9286

www.jESE-online.org

Original scientific paper

\title{
Electrocoagulation: an electrochemical process for water clarification
}

Éva Fekete, Béla Lengyel, Tamás Cserfalvi*, Tamás Pajkossy $₫$

Institute of Materials and Environmental Chemistry, Research Centre for Natural Sciences, Hungarian Academy of Sciences, Magyar tudósok körútja 2., Budapest, H-1117, Hungary

*IC-Produkt Co, Puskás Tivadar út 14. C/B, Budaörs, H-2040, Hungary

${ }^{\square}$ Corresponding Author: pajkossy.tamas@ttk.mta.hu; Tel.: +36-3826-496

Received: September 12, 2015; Accepted: November 26, 2015

\begin{abstract}
Electrocoagulation is a group of various procedures used for removing contaminants from water by electrochemically dissolving aluminum or iron. The contaminants of the solution may be incorporated in the in situ forming metal hydroxide flocs, which can be filtered as a precipitate or skimmed as a float. The main features of the procedure are highlighted on the example of cleaning of an oily waste-water. Design parameters of a $1 \mathrm{~m}^{3} / \mathrm{h}$ waste-water cleaning system are calculated from the results of small-scale experiments.
\end{abstract}

\section{Keywords}

Waste-water; Flotation; Flocculation; Pollution; Adsorption; Colloid

\section{Introduction}

Electrocoagulation is a collective term for a couple of procedures that are generally used for removing various - mostly suspended material type - contaminants from water. These procedures were invented more than a century ago and attempted to apply for many and diverse systems. The existing literature is of industrial/technical rather than of scientific nature; good overviews of the topic are in Refs. [1-3].

The basics of all of these procedures are as follows: Assume an electrolysis cell with a metal ( $\mathrm{Me}=\mathrm{Al}$ or $\mathrm{Fe}$ ) anode, and some neutral aqueous solution with direct current, $d c$, flowing through it. On the cathode hydrogen evolution, on the anode metal dissolution proceeds, the metal dissolution yields $\mathrm{Me}^{2+}\left(\mathrm{Al}^{3+}\right.$ or $\mathrm{Fe}^{2+}$ or $\left.\mathrm{Fe}^{3+}\right)$ ions. These cations induce decontamination by two different ways: 
(1) The ions of high positive charge, in accord with the Schulze-Hardy rule [4], cause the coagulation of the contaminant colloids of negative surface charge. Decontamination in this case - called "discharge coagulation" - means that the colloids coalesce and finally are separated from the liquid phase.

(2) In neutral aqueous solutions the hydrolysis of the $\mathrm{Me}^{2+}$ proceeds immediately yielding $\mathrm{Me}(\mathrm{OH})_{z}$. The growth of $\mathrm{Me}(\mathrm{OH})_{z}$ particles starts as polynuclear complexes, continues as growth of colloids, which finally merge yielding flocs. During the growth, certain components of the solutions, like the contaminating particles, substances can be incorporated in the flocs, thereby the flocs finally comprise of the metal-hydroxide and the contamination. Decontamination effect is a consequence of incorporation, which is much more pronounced at the initial stage of the hydroxide formation. In other words, the "nascent" $\mathrm{Me}(\mathrm{OH})_{z}$ colloids are the active particles rather than the big flocs. This mechanism of decontamination is called "sweep coagulation".

Depending on their specific density, the merged particles are separated from the liquid in two ways: either precipitate, or form a float or a scum (note that even the relatively heavy flocs may float if are attached to hydrogen bubbles evolved on the cathode). The difference between the two basic separation techniques of the electrocoagulation: electroflocculation and electroflotation, is ultimately based on the specific density of the merged particles (sink or swim).

Here we note that $\mathrm{Me}^{z+}$ ions just as the $\mathrm{Me}(\mathrm{OH})_{z}$ colloids can be generated by simply dissolving Me-salts in water, the main advantage of the electrochemical generation of the coagulant ion (over that of dissolving the salts) is that electrochemically the "nascent" colloid is formed and introduced in the bulk of the solution in a much more controlled way. From the technical viewpoint a further important advantage is the simple unit design without external solution dosing. For a comparison, see, e.g. Ref. [5] or chapters 3-5 of [3].

Various sorts of electrocoagulation - as water cleaning, or waste-water processing industrial procedures - have been introduced since the beginning of the past century. However, due to big energy costs and to various technical problems (e.g. inhibition of electrodes' dissolution) the procedure could not penetrate in industrial water- and waste-water processing up till recently. In the recent years a number of enterprises have appeared and are selling electrocoagulation process units, typically with $1-10 \mathrm{~m}^{3} / \mathrm{h}$ capacity. Also the number of the technical papers have been increasing in the past twenty years. Most of these are on experiments on removal of some, usually organic contaminants from some wastewater. The list of the substances which can be - or at least were attempted to be - removed is fairly long; for a listing of the systems see Ref. [6]. Many of the systems are oily emulsions associated with petrol industry [7-13] or with vegetable oils [14-18] or with mechanical industries [19-21]. Nevertheless, removal of inorganic compounds (e.g. heavy metals from groundwater or from effluents of various metal industries) has also been implemented. It must be noted that the efficacy of the wastewater cleaning through coagulationflocculation process is generally low in the removal of the dissolved organic components.

Our motivation - just as the subject of the present paper - is associated with a project of ICProduct Co. (Hungary) aimed at the development of a mobile, $1 \mathrm{~m}^{3} / \mathrm{h}$ capacity electrocoagulation waste-water cleaning unit. For the development, basic design parameters data were needed mostly on the material- and energy balances. To this end, we performed small-scale experiments with oil-in-water type emulsions, whose organic content was in the $1 \mathrm{~g} / \mathrm{L}$ order-of-magnitude. The work is aimed at to answer the following three main questions:

1. How much metal is to be dissolved electrochemically to coagulate a certain amount of organics? 
2. What is the efficiency of the organic material removal and how much energy is needed to remove the organic material?

3. What are the important aspects of electrochemical cell design?

In what follows we show demonstration experiments, carried out with a commercially available oil-in-water emulsion used as a cooling lubricant for cutting and drilling, providing the guidelines to answer the above questions. We focus mainly on the behaviour of Al electrodes; in some cases, for comparison, the results of analogue experiments with iron electrodes are also shown. We note that the technical issues associated with settling of the flocs, filtering the sludge, removing the float is just as difficult as the electrochemistry involved. These problems, however, are not discussed here.

\section{Experimental}

We used a non-thermostatted rectangular-channel flow-through cell, shown in Fig. 1, containing vertically placed parallel-plate electrodes (height $10 \mathrm{~cm}$, width $5 \mathrm{~cm}$, interelectrode distance, $w, 0.2 \mathrm{~cm}$ ). The electrolyte was pumped through in upward direction by a peristaltic pump providing a flow rate in the $1-16 \mathrm{~L} / \mathrm{h}, \sim 0.3-4 \mathrm{~mL} / \mathrm{s}$ range.

a

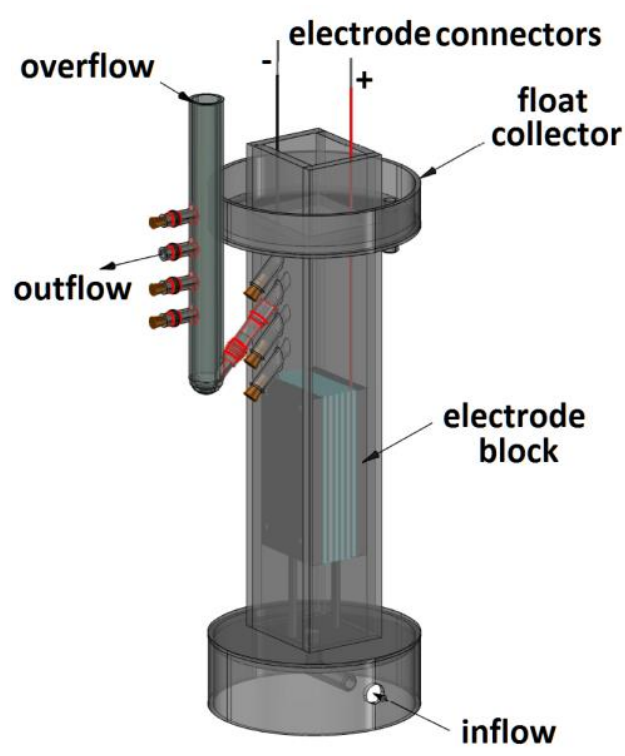

b

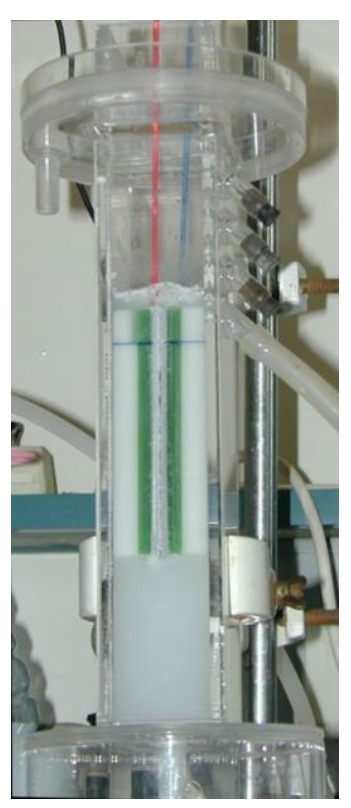

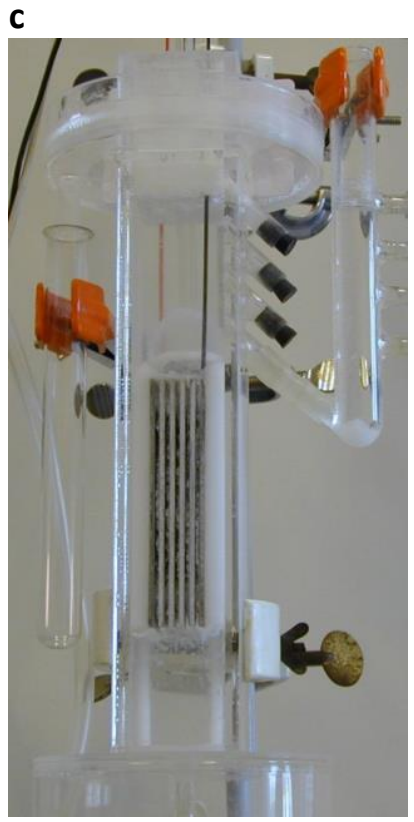

Figure 1. The flow through cell used in the experiments (a). By changing the assembly of the electrode block, it could be used with 2 monopolar electrodes (b) and with maximum 6 electrodes comprising 5 serially connected cells with bipolar electrodes (c).

The current - cell voltage measurements have been performed in galvanostat mode by an EF 427E high-power potentiostat, the voltage and/or current data were collected by DVMs via RS-232 interfacing. The typical precision of the measured voltages and current is $1 \mathrm{mV}$ and $0.1 \%$, respectively.

The Al electrodes were made of technical alumínum alloy plates (AIMgSi0.5 alloy of standard EN AW 6060). In some cases, for comparison Fe (carbon steel with $0.2 \% \mathrm{Mn}$ and $0.2 \%$ Si content of standard 10130) electrodes were also used. In some cases the metal content of the effluent after acidifying the samples - was determined by inductively coupled plasma spectrometry (ICP). 
Solutions: The oil emulsion is a commercially available oil product of MOL Co. (Hungary) with trade name Emolin 400, major components of which are emulsified mineral oil (60-65 w/w \%), surfactants (11-23 w/w \%) and organic corrosion inhibitors (15-20 w/w \%). Its 2-5\% aqueous dilution is widely used in factories, machine shops as a cutting \& drilling cooling lubricant. We note that the results obtained with this oil emulsion are rather similar to those with other emulsions - like diluted bovine milk, or oil-in-water emulsions of olive oil. The typical dilution in our experiments was $1 \mathrm{~g} / \mathrm{L}$, for which the total organic content, measured by the regular chemical oxygen demand method (COD, determined by digesting the appropriately diluted sample by potassium bichromate and titrating back the residual bicromate [22]) was found to be around $2000 \mathrm{mg} \mathrm{COD} / \mathrm{L}$. The solutions of the metal dissolution experiments have been made with pure chemicals $\left(\mathrm{Na}_{2} \mathrm{SO}_{4}\right.$ and $\mathrm{NaCl}$ ) from Reanal or Fluka, in deionized water produced by an ELGA purewater system.

\section{Results}

When the white-opaque oil-water emulsion is electrolyzed between Al or Fe electrodes, first the metal hydroxide changes the appearance of the emulsion. Provided that a sufficient charge has passed through the cell, after a certain time - typically within a couple of hours - the flocs are settled, the liquid above the flocs gets become clear, as shown in Fig. 2.

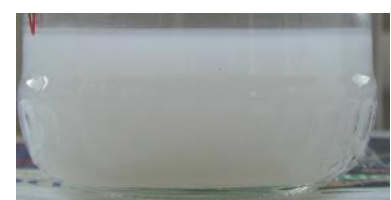

$300 \mathrm{C} / \mathrm{L}$

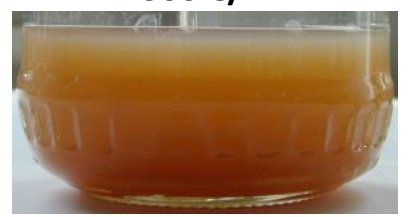

$420 \mathrm{C} / \mathrm{L}$

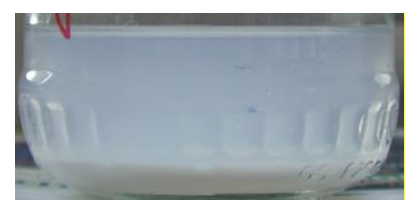

$360 \mathrm{C} / \mathrm{L}$

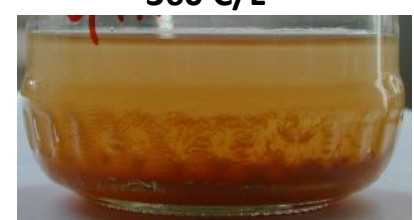

$480 \mathrm{C} / \mathrm{L}$

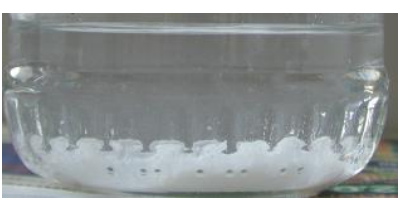

$420 \mathrm{C} / \mathrm{L}$

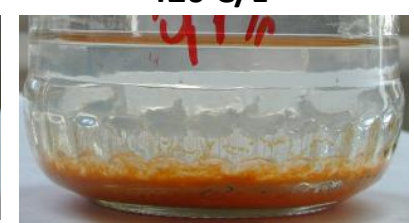

$600 \mathrm{C} / \mathrm{L}$

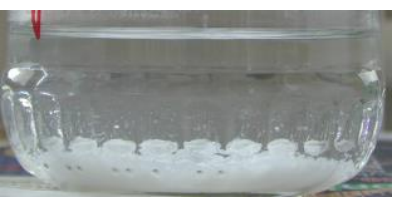

$540 \mathrm{C} / \mathrm{L}$

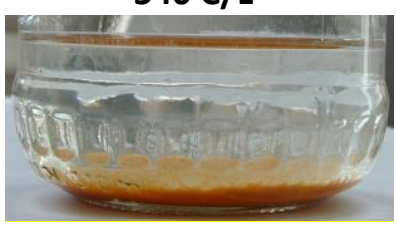

$720 \mathrm{C} / \mathrm{L}$

Figure 2. Emolin-water emulsion (0.1\% for Emolin) after electrolysis and 1 day settling. The charge/volume data are under the photos. 1st and 2nd row of photos: electrolysis with Al$\mathrm{Al}$ and $\mathrm{Fe}$-Fe electrodes, respectively.

The cleaning effect can be quantified by measuring turbidity of the liquid after the settling. When turbidity is low and the dissolved components are colorless, optical absorption in the visible range is also a good measure of suspended particles. Hence, the amount of coagulant needed to achieve complete - or at least the maximum possible - coagulation can be easily measured by measuring the optical absorption spectra of the clear part of the liquid as function of the charge passed through the electrodes. This is shown in Fig. 3a. Three features are important: first, there exists a threshold value of charge (in what follows, named as coagulation charge) above which the absorbance (just as turbidity) is negligible, i.e. suspended particles disappear from the liquid; second, coagulation charge is almost the same for $\mathrm{Al}$ as for Fe electrodes and third, the coagulation charge is proportional to the oil concentration, as shown in Fig. 3b. 

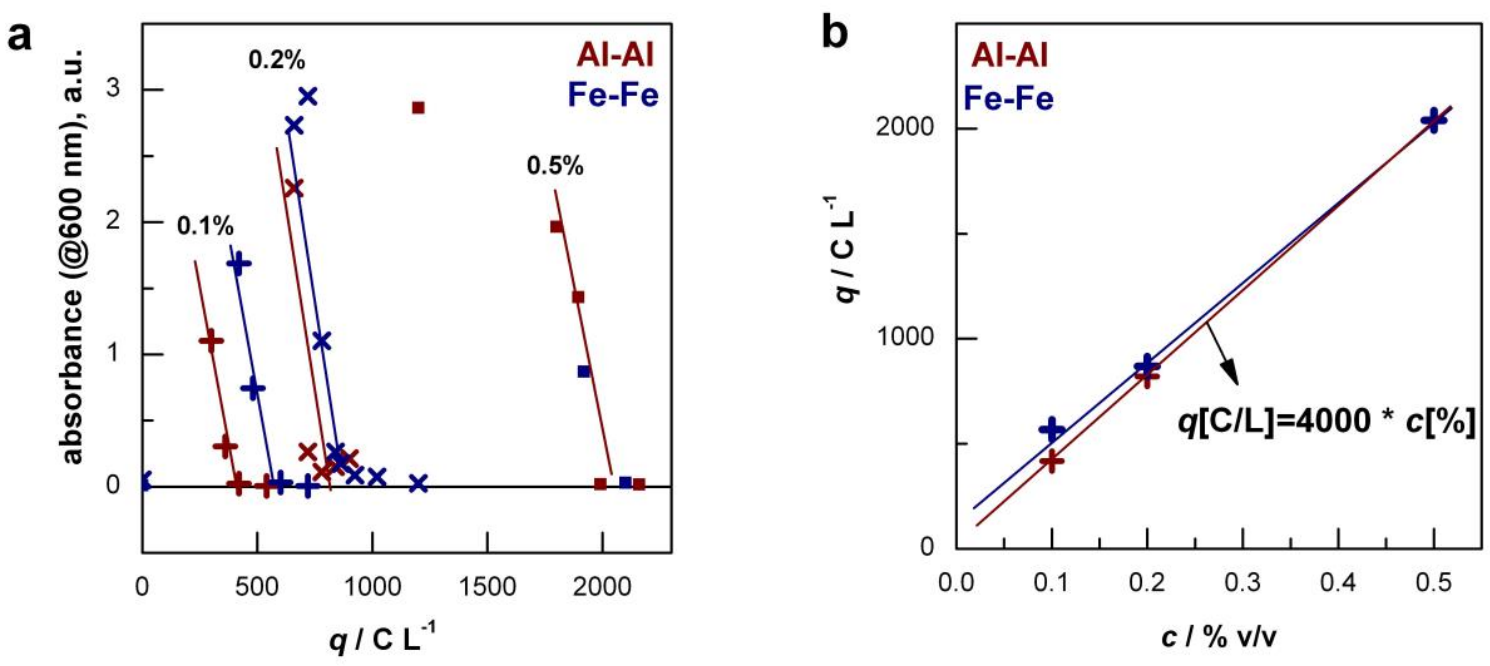

Figure 3. (a) Absorbance of the clear part of the liquid as function of charge passed between Al-Al electrodes (red symbols) and between Fe electrodes (blue symbols) for emolin-water emulsions of concentrations as indicated. (b) Charge needed for the effective coagulation.

Based on the "calibration line" on Fig.3b, provided that the oil concentration, $c$, is known, we can calculate the amount of charge needed to coagulate the oil content of unit volume of the liquid as $q$ / $C=4000 \times c / \%$. Charge and dissolved metal's moles, $m$, is connected by Faraday's law as $m=q /\left(n_{\mathrm{e}} F\right)$, where $F=96500 \mathrm{C} / \mathrm{mol}$, and $n_{\mathrm{e}}$ is the effective charge number, which can be determined by measuring charge, and the metal content of the liquid (flocs, sludge, scum, float, and clear liquid altogether) by ICP. The $n_{e} \equiv q / m$ F effective charge number has been calculated from a number of dissolution experiments; its value is $\approx 2$ both for $\mathrm{Al}$ and Fe, because of different reasons:

a. The $n_{\mathrm{e}} \approx 2$ for $\mathrm{Al}$ is an indication that $\mathrm{Al}$ is dissolved on both electrodes. On the cathode hydrogen evolution, i.e. strongly reducing conditions keep the Al surface oxide-free, hence the Al being an "electronegative" metal - chemically splits water according to the reaction:

$$
2 \mathrm{Al}+6 \mathrm{H}_{2} \mathrm{O}=2 \mathrm{Al}(\mathrm{OH})_{3}+3 \mathrm{H}_{2} .
$$

The fact that Al dissolves also cathodically, is well-known in corrosion science[23] and has also recognized in electrocoagulation studies [24,25].

b. Iron dissolves in $\mathrm{Fe}^{2+}$ form - this is clearly seen as the solution becomes dark green in the vicinity of the anode. However, the dark green flocs slowly (typically in 10 minutes - 1 hour time, depending on the conditions) get the pale brown colour of the $\mathrm{Fe}^{3+}$, just as seen in Fig. $2,2^{\text {nd }}$ row.

The effectivity of the cleaning procedure can be determined by chemical analysis of the sludge and of the cleaned liquid: the total organic content of the liquid, approximated and measured as COD, decreases to $10-20 \%$ that of the original emulsion containing approximately this amount of dissolved organics (in what follows we consider the average, $15 \%$ ). With these data, the mass balance can be estimated, as follows: Assume an oily waste water of $0.1 \% \approx 1 \mathrm{~g} / \mathrm{L}$ organic content. To remove $85 \%(\approx 850 \mathrm{mg})$ of the organics, $\approx 400 \mathrm{C}$ is needed; with this charge $\approx 400 /(2 * 96500) 27 \mathrm{~g}=56 \mathrm{mg} \mathrm{Al}$ or $\approx 400 /(2 * 96500) 56 \mathrm{~g}=116 \mathrm{mg}$ Fe is dissolved.

The energy consumption of an electrocoagulation cell is much less well-defined. To illustrate this, lets perform the current - cell potential (polarization curve) measurement between the two Al electrodes, in a solution, whose conductivity, $\kappa$, is similar to that of some tap water, $\approx 500$ $\mathrm{mS} / \mathrm{cm}$ or somewhat larger. To avoid passivation of these metals, the electrolyte should contain 
some chloride - the minimum concentration was reported to be $60 \mathrm{ppm}$ chloride $(=1.7 \mathrm{mM})$ [26]. To be safely above this low limit, the polarization curves have been measured in $20 \mathrm{mM} \mathrm{NaCl}$ solution $\left(\kappa \approx 2.3 \mathrm{mS} / \mathrm{cm}\right.$ at $\left.25^{\circ} \mathrm{C}\right)$; such a curve is shown in Fig. 4 . First, In the range of $\pm 1 \mathrm{~V}$ the curve has a clockwise hysteresis, clearly indicating passivation-depassivation. In this cell voltage range - or with smaller currents than $5 \mathrm{~mA}-\mathrm{Al}^{3+}$ ions thicken the oxide layer on the electrode rather than enter the solution. Hence the cell voltage must be larger than approximately $1 \mathrm{~V}$; the use of $10 \mathrm{~mA} / \mathrm{cm}^{2}$ current density seems to be reasonable. Out of the $\pm 1 \mathrm{~V}$ range, $U \approx 1 \mathrm{~V}+I R$. The straight lines starting at $+1 \mathrm{~V}$ and $-1 \mathrm{~V}$ are in the IR drop-controlled voltage ranges. The reciprocal of the slopes of the lines $=1 / 3.07 \mathrm{mS} \mathrm{cm}{ }^{2}=325 \Omega \mathrm{cm}^{2}$, are larger by a factor of almost 4 than the area-normalized resistance of the solution between the electrodes $A R=w \kappa=87 \Omega \mathrm{cm}^{2}$. This difference indicates that the electrode surfaces are covered by some layer of significant resistance. In fact, white layers can be seen on the electrodes after the experiments; their appearance depends on the experiment's conditions. For example, if high $d c$ current flows along with fast streaming of the electrolyte for a long time, then the layer is practically missing; the resistance is that of the solution. This is why we specify the lower limit of the cell voltage as $U=1 \mathrm{~V}+I R=1 \mathrm{~V}+j w / k$ for the cases of surface-layer-free, "clean" electrodes where the $I R$ drop is due to solution resistance only. In real systems, the $I R$ terms may be somewhat larger.

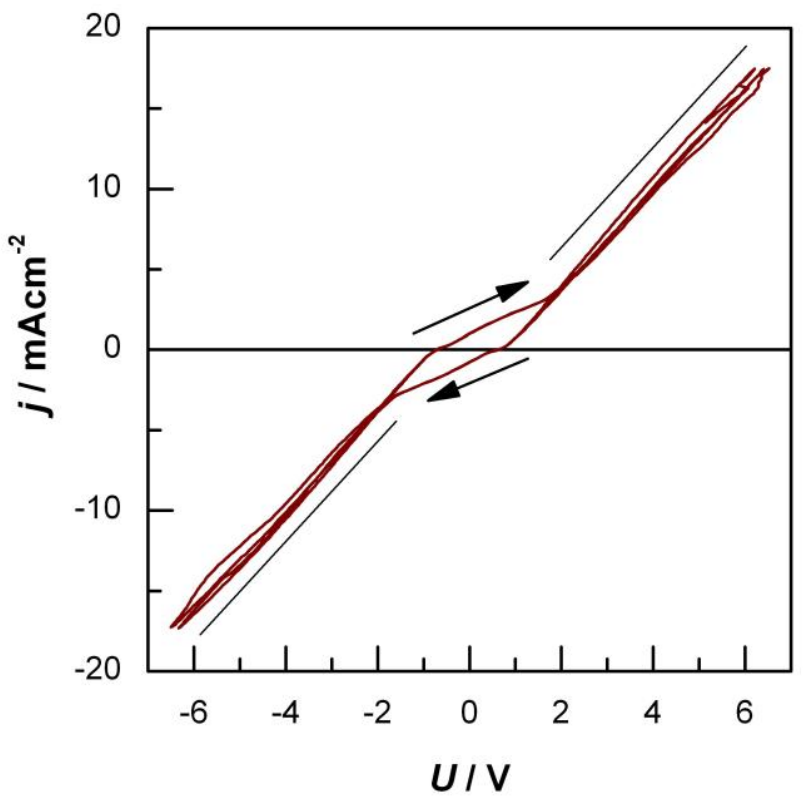

Figure 4. Polarization curve measured galvanostatically $\left(0.66\left(\mathrm{~mA} / \mathrm{cm}^{2}\right) / \mathrm{s} \mathrm{scan}\right.$ rate) in $20 \mathrm{mM}$ $\mathrm{NaCl}$ solution in a flow cell of thickness $2 \mathrm{~mm}$, between two Al electrodes. Flow rate $1 \mathrm{~L} / \mathrm{h}$.

With these considerations, energy consumption is estimated as follows: Employing typical values, $j=10 \mathrm{~mA} / \mathrm{cm}^{2}, k=2 \mathrm{k} \Omega \mathrm{cm}$ (usual value for tap water), $w=0.5 \mathrm{~cm}$, and clean electrodes we get an inacceptably high value of $U=11 \mathrm{~V}$. (Note that in this case almost the full amount of electricity heats the cell.) Since in practical cases the interelectrode distance cannot be decreased in order to avoid blocking of the cell; with smaller currents the electrodes are prone to get passivated; the only possibility to decrease cell voltage, salt addition to the liquid is inavoidable.

Finally, the energy consumption is calculated with the assumption that the cell voltage can be lowered to $5 \mathrm{~V}$. While passing $400 \mathrm{C}$ charge, $5 \mathrm{~V} \times 400 \mathrm{C}=2000 \mathrm{~J} \approx 0.55 \mathrm{Wh}$ energy is consumed. 
Mass balance and energy consumption on a practical scale, based on the above data: for removing approximately $1 \mathrm{~kg}$ oily contaminant from a waste water of about $1 \mathrm{~m}^{3}$, we need $56 / 0.85=66 \mathrm{~g} \mathrm{Al}$ and $0.55 \mathrm{kWh}$ electric energy for performing the electrocoagulation.

For these data of mass of $\mathrm{Al}$ and electric energy, two comments are needed. First, the aluminium plates used as electrodes are dissolved somewhat unevenly. We found that (on an average) about $90 \%$ of their mass can be utilized. Second, we found that in some cases certain coatings are formed on the cathode (a sticky organic or limescale) which can be removed by changing the polarity for a while. Prompted by some studies whose authors advocate for the use of alternating current, $a c$, rather than $d c[27,28]$ we now demonstrate the worse performance of the ac method with the following experiment:

The current of the flow-through cell with Al electrodes was set to a value at which the Al concentration of the effluent was $2.5 \mathrm{mM}$. Then, $d c$ of alternating polarity was applied polaritychanges in every $t$ seconds ( $5 \mathrm{~ms} \leq t \leq 50 \mathrm{~s}$ ). The Al content of the effluent was measured by ICP. The Al content decreases with decreasing $t$, as shown in Fig. 5 , clearly pointing to that electrocoagulation should be done with $d c$. Polarity changes should be done rarely, only if needed. As a matter of curiousity: alternating the polarity blocks Fe electrodes much more than Al ones.

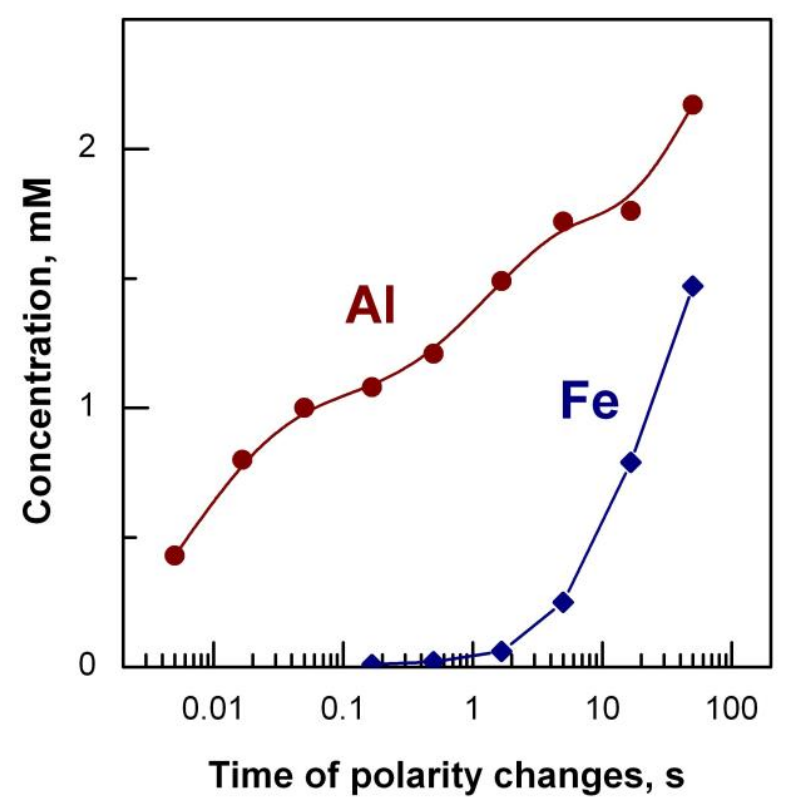

Figure 5. Dependence of metal dissolution rate on frequency of the current of alternating polarity. Abscissa: time between polarity changes (half of period time); ordinate: concentration of dissolved metal ( $\mathrm{Al}$ or Fe) in the effluent. With dc electrolysis, the concentration is $2.5 \mathrm{mM}$.

\section{Discussion}

On the whole, the obtained data of cleaning efficiency (mainly COD) are in agreement with those in papers on similar studies [18-20]. Thus, we can specify the design parameters for the waste water cleaning unit of $1 \mathrm{~m}^{3} / \mathrm{h}$ capacity, with assuming a $1 \mathrm{~kg} / \mathrm{m}^{3}=1 \mathrm{~g} / \mathrm{L}$ oily contamination, as follows:

1. The unit will remove $85 \%$ of the contamination (in terms of COD). Provided that COD is proportional to concentration of the organics, the rest is the dissolved organics of $0.15 \mathrm{~g} / \mathrm{L}$, with COD $300 \mathrm{mg} / \mathrm{L}$. 
We note that this residual contamination level might imply that a secondary purification step of activated carbon adsorption is required. However, this water quality generally fits to reuse purposes in industrial applications.

2. To remove $1 \mathrm{~kg}$ organics, approximately $66 \mathrm{~g} \mathrm{Al}$ is to be dissolved. For this, $(66 / 27) \times 2 \times 96500=0.47 \times 10^{6} \mathrm{C}$ charge is needed in one hour, i.e. $\approx 131 \mathrm{C} / \mathrm{s}$. Provided that we use $10 \mathrm{~mA} / \mathrm{cm}^{2}$ current density, the area of anodes and cathodes is $\approx 131 \mathrm{~A} /\left(0.01 \mathrm{~A} / \mathrm{cm}^{2}\right) \approx$ $\approx 1.3 \mathrm{~m}^{2}$.

3. As it has been found in the context of Fig.4, the cell voltage is $U \approx 1 \mathrm{~V}+I R=1 \mathrm{~V}+j w / \kappa$; with 0.5 $\mathrm{cm}$ interelectrode distance the cell voltage and hence energy consumption are inacceptably high if the conductivity of the waste water is like that of tap water. For the increase of conductivity, salt, $\mathrm{NaCl}$ - or salt plus for balancing $\mathrm{pH}, \mathrm{HCl}$ - should be added to the waste water - up till it reaches the maximum emission value of waste water, $2 \mathrm{mS} / \mathrm{cm}$. This requires less than $1 \mathrm{~kg} \mathrm{NaCl}$ (per $1 \mathrm{~m}^{3}$ waste water). Then $U \approx 1 \mathrm{~V}+10 \mathrm{~mA} / \mathrm{cm}^{2} \times 0.5 \mathrm{~cm} /(2 \mathrm{~ms} / \mathrm{cm})=3.5 \mathrm{~V}$. We note that from energy consumption point of view the continuous conductivity monitoring and adjusting system plays a central role.

4. Points 2+3: The dissolution of $66 \mathrm{~g}$ Al requires $0.47 \times 10^{6} \mathrm{C} \times 3.5 \mathrm{~V}=1.65 \mathrm{MJ}=0.45 \mathrm{kWh}$ electric energy. The overall electrode area of $1.3 \mathrm{~m}^{2}$ may be divided to many small sections to yield an ensemble of parallely and serially connected cells, thus the power supply can be set up employing parallely operating e.g. $24 \mathrm{~V}$ modules.

Although there is a number of other important issues (e.g. $\mathrm{pH}$ regulation, flow control, separation of flocs and float, detection of electrodes' blockage) which are out of our present scope, the main electrochemical points of electrocoagulation have all been presented here. Using also these guidelines, which were formulated based on our small-scale experiments, a couple of prototypes of electrocoagulation waste water cleaning units have been built; their properties are close to those predicted.

\section{Conclusions}

The subject of this paper is a couple of small-scale experiments by which design parameters of larger-scale electrocoagulation units could be established. As a result of these experiments with oil-in-water type emulsions with about $1 \mathrm{~kg} / \mathrm{m}^{3}$ organic content, we conclude that $80-90 \%$ of the organic content can be removed on the expense of dissolution of Al of less than one-tenth of mass of the removed organics plus about $0.5-1 \mathrm{kWh}$ electric energy per kg of removed organics.

Acknowledgements: The project of code KMR_12-1-2012-0386 was funded by the National Research, Technology and Innovation Office of the Hungarian government.

\section{References}

[1] M. Vepsäläinen: Electrocoagulation in the treatment of industrial waters and wastewaters, Thesis, VTT Technical Research Centre of Finland, 2012

[2] M. Y. A. Mollah, R. Schennach, J. R. Parga, and D. L. Cocke, Journal of Hazardous Materials, 84 (2001) 29-41.

[3] O. Sahu, B. Mazumdar, P. K. Chaudhari, Environ. Sci. Pollut. Res. 21 (2014) 2397-2413.

[4] IUPAC Compendium of Chemical Terminology (Gold Book), http://old.iupac.org/goldbook/S05501.pdf (accessed on June 28, 2015)

[5] P. Canizares, F. Martinez, C. Jimenez, C. Saez, M. A. Rodrigo: J. Hazard. Mater. 151 (2008) $44-51$ 
[6] M. M. Emamjomeh, M. Sivakumar, J. Environ.Management 90 (2009) 1663-1679

[7] Y. O. A. Fouad, A. H. Konsowa, H. A. Farag, G. H. Sedahmed, Chem. Eng. J. 145, 436-440 (2009)

[8] M. Karhu, V. Kuokkanen, T. Kuokkanen, J. Ramo: Separation and Purification Technology 96 (2012) 296-305

[9] M. H. El-Naas, S. Al-Zuhair, A. Al-Lobaney, S. Makhlouf, J.Environ. Manag. 91 (2009) 180185

[10] Yusuf Yavuz, A. Savas Koparal, Ülker Bakır Öğütveren, Desalination 258 (2010) 201-205

[11] Muftah H. El-Naas, Sulaiman Al-Zuhair, Amal Al-Lobaney, Souzan Makhlouf, Journal of Environmental Management 91 (2009) 180-185

[12] Rupesh M. Bande, B. Prasad, I.M. Mishra, Kailas L. Wasewar, Chemical Engineering Journal 137 (2008) 503-509

[13] Rupesh M. Bande, B. Prasad, I.M. Mishra, Kailas L. Wasewar, Chemical Engineering Journal 137 (2008), 503-509

[14] O. Chavalparit, M. Ongwandee, J.Environ. Sci. 21 (2009) 1491-1496

[15] U. T. Un, A. S. Koparal, U. B. Ogutveren, J. Environ. Manag. 90 (2009) 428-433

[16] N. Azbar, T. Yonar, Process Biochem., 39 (2004) 869-875

[17] X. Chen, G. Chen, P.L. Yue, Sep. Purif. Technol. 19 (2000) 65-75

[18] X. Xu, X. Zhu, Chemosphere 56 (2004) 889-894

[19] M. Khemis, G. Tanguy, J. P. Leclerc, G. Valentin, F. Lapicque, Process Safety and Environmental Protection, 83(B1) (2005) 50-57

[20] K. Bensadok, S. Benammar, F. Lapicque, G. Nezzal, Journal of Hazardous Materials 152 (2008) 423-430

[21] Mohamed Tir, Nadji Moulai-Mostefa, Journal of Hazardous Materials 158 (2008) 107-115

[22] ISO 6060: Water quality -- Determination of the chemical oxygen demand (1989)

[23] E. P. G. T. van de Ven, H.Koelmans, J. Electrochem. Soc. 123 (1976) 143-144

[24] P. Canizares, M. Carmona, J. Lobato, F. Martınez, and M. A. Rodrigo, Ind. Eng. Chem. Res., 44 (2005), 4178-4185

[25] G. Mouedhen, M. Feki, M. D. P. Wery, H.F. Ayedi, J Hazardous Mat. 150 (2007) 124-135

[26] M. Mechelhoff, G.H. Kelsall, N. J. G. Graham, Chem. Eng. Sci. 95 (2013) 301-312

[27] N. P. Barkley, C. Farrell, T. Williams, EPA/540/S-93/504 (1993)

[28] S. Vasudevan, J. Lakshmi, and G. Sozhan, J Hazard Mater, 192 (2011) 26-34

(C) 2016 by the authors; licensee IAPC, Zagreb, Croatia. This article is an open-access article distributed under the terms and conditions of the Creative Commons Attribution license (http://creativecommons.org/licenses/by/4.0/) (cc) EY 